\title{
KRISTOLOGI “LOGOS” DAN KONTEKS PLURALISME AGAMA
}

\section{Nelson Semol Kalay}

\begin{abstract}
The incarnation of "Logos" is an essential and important theme in Christian theological discourse. In the context of religious pluralism today this Christology is critically reviewed by theologiansbased on the assumption that it is too exclusive and does not promote the interreligious dialogue. In this article I try to examine that assumption based on the biblical investigation to the concept of Logos, especially in the Gospel of John. According to John, Logos has three important roles as theagent of creation, revelation, and salvation. As the agent of creation Logos is presented as God's co-creator who partook in the creation of "all" (panta). In term of his role in revelation and salvation, Logos is presented as the Incarnated who liberated people from suffering through 'the signs' as noted in the Gospel. These three interesting ideas of Logos of the Gospel of John - especially universality of Logos and the liberation Christology of religions - will finally be reflected in the context of religious pluralism.
\end{abstract}

Keywors : Logos, God, Christology, Religious Pluralism

\begin{abstract}
Abstrak
Inkarnasi Logos merupakan suatu tema yang penting dalam wacana teologi Kristen. Dalam konteks pluralisme saat ini Kristologi ini ditinjau kembali secara kritis oleh para teolog (terutama teolog agama-agama) berdasarkan pada asumsi bahwa gagasan ini sangat eksklusif dan tidak mempromosikan dialog antar agama. Dalam artikel ini saya mencoba untuk menguji kembali asumsi ini dengan didasarkan pada investigasi biblis terhadap konsep Logos, terutama konsep Injil Yohanes. Menurut Yohanes, Logos memiliki tiga peran penting sebagai agen penciptaan, agen penyataan, dan agen penyelamatan. Sebagai agen penciptaan Logos diperkenalkan sebagai mitra Allah dalam penciptaan 'semua' (panta). Dalam hal peran penyataan dan penyelamatan, Logos ditampilkan sebagai yang berinkarnasi yang membebaskan orang dari penderitaan melalui 'tanda-tanda' sebagaimana dicatat di dalam Injil Yohanes. Tiga ide yang menarik tentang Logos Yohanes ini - terutama gagasan universalitas Logos dan Kristologi pembebasan agama-agama - pada akhirnya akan direfleksikan dalam konteks pluralisme agama.
\end{abstract}

Kata Kunci : Logos, Allah, Kristologi, Pluralisme Agama 


\section{KONSEP "LOGOS" SEBAGAI DASAR KRISTOLOGI INKARNASI}

Dalam sejarah kekristenan, kristologi inkarnasi mendapat tempat yang sentral dan signifikan. Maurice Wiles mengatakan bahwa sentralitas kristologi ini membuat kekristenan cenderung diidentikan sebagai incarnational faith. ${ }^{\mathrm{i}}$ Mungkin untuk alasan ini C. Gore mengungkapkan bahwa jika konfesi inkarnasi diabaikan, maka kekristenan dalam karakteristik uniknya juga akan terabaikan. ${ }^{\text {ii }}$ Dalam perkembangan kemudian, konsep inkarnasi banyak menuai kontroversi dari berbagai kalangan yang mempertanyakan kemungkinan Allah menjadi

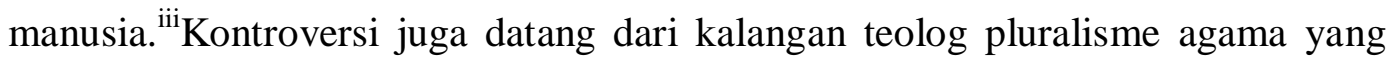
memandang kristologi ini sebagai ancaman bagi kehidupan antaragama. Misalnya, John Hick dalam rangka mengembangkan suatu teologi yang "teosentris", dimana Allah menjadi universal dan agama-agama diposisikan sejajar, maka ia menuding bahwa gagasan inkarnasi harus dilihat sebagai suatu mitos yang perlu dipertimbangkan kembali. Bagi Hick, mitos ini bertanggung jawab atas kecenderungan eksklusifisme kekristenan atas agama-agama lain karena menempatkan Yesus sebagai figur sentral dan karena itu kekristenan dianggap satu-satunya agama sahih. Hick menulis: "the Incarnation doctrine entails that the Christian religion, alone among the religions of the world, was founded by God in person - for it is part of traditional orthodoxy both that there has been only one incarnation, and that Jesus, who was God incarnate, instituted the Christian church. And it seems obvious that having come to earth to found a new religion God must intend it to supersede all other religions and to embrace the entire human race."

Alasan kedua Hick menolak kristologi inkarnasi ialah pandangan ini dilihat bukan sebagai ajaran Yesusv ${ }^{\mathrm{v}}$, tetapi merupakan produk gereja sebagai sebuah institusi. Pernyataan-pernyataan kristologis pada dasarnya merupakan pernyataanpernyataan konfesional gereja yang lahir dari pergumulan panjang kekristenan dan bukan merupakan pernyataan langsung yang diberikan oleh figur historis Yesus. Leslie Houlden mengatakan bahwa semua kristologi itu ialah hasil interpretasi terhadap arti Yesus. ${ }^{\mathrm{vi}}$ Bahkan dengan menyebutnya sebagai 'ikon kristologis',Don 
Cuppit menggarisbawahi bahwa penggambaran-penggambaran kristologis itu tidak bersifat alkitabiah.

Terlepas dari penolakan-penolakan para teolog yang melihatnya sebagai ancaman bagi pluralisme agama, saya justru sebaliknya akan menelusuri kemungkinan lain dari gagasan ini. Saya tidak membantah bahwa kristologi ini samasekali bebas dari kecendrungan eksklusifisme, tetapi pun tidak serta-merta setuju bahwa kristologi inkarnasi harus ditinggalkan sebagaimana tawaran Hick tadi. Sebaliknya, melalui artikel ini saya akan menyoroti dimensi lain dari kristologi inkarnasi yang dapat memberi kontribusi bagi pengembangan teologi agama-agama. Dalam konteks inilah, investigasi biblisakan dilakukan untuk memahami inkarnasi Yesus melalui eksplorasi terhadap makna Logos.

Kristologi inkarnasi berakar dan berkembang dari pemikiran injil Yohanes mengenai "Logos". Mangapul Sagala dengan mengutarakan pemikiran R. E. Brown dan W. R. Cook menandaskan bahwa konsep ho Logos sarks egenetodalam Yohanes 1 merupakan dasar kristologi inkarnasi. Fakta inkarnasi sangat penting dalam tulisan-tulisan Yohanes (Brown) dan menjadi salah satu tema utama dalam injil Yohanes (Cook). ${ }^{\text {vii }}$ T. E. Pollard juga menekankan hal yang sama, bahwa tema inkarnasihanya dapat ditemukan di dalam Injil dan Surat-surat Yohanes yang muncul untuk meresponi bahaya doketisme saat itu (ajaran yang hanya menekankan sifat keilahian Yesus). ${ }^{\text {viii }}$ Dengan demikian, maka dalam artikel ini pertama-tama saya akan menyoroti konsep Logos yang muncul sebelum Injil Yohanes, kemudian konsep Yohanes mengenai Logos dan berakhir dengan interpretasi kristologi Logos atau inkarnasi dalam konteks pluralisme agama.

\section{KONSEP LOGOS DAN TRADISI PEMIKIRAN PRA-YOHANES}

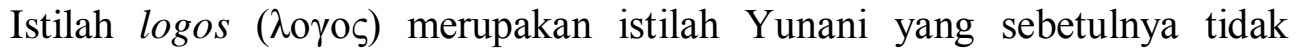
memiliki makna tunggal. Sagala dengan mengikuti C. H. Dodd memperlihatkan bahwa kata ini memiliki makna yang sangat luas sebab tergantung pada konteks penggunaannya. Sementara itu C. K. Barrett menajamkannya dengan mengatakan bahwa Logos harus dipahami dalam konteks tradisi teistik dan non-teistik, sebagaimana yang dipaparkan di bawah ini. ${ }^{\text {ix }}$ 
Theological Dictionary of the New Testamentmemberi beberapa arti kata ini sesuai konteks umum penggunaannya; (i) logos berarti "menyebut berturut-turut" (counting up), "menceritakan" (recounting) untuk menunjuk pada suatu narasi lengkapserta kata-kata individu yang digunakan untuk menyebutkan "pidato" atau "bahasa", "kalimat", dan "perkataan"; (ii) Logos juga bisa berarti "cerita" (account), "perhitungan" (reckoning), atau "hasil perhitungan" (result of reckoning); (iii) Istilah logos juga digunakan sebagai istilah teknis dalam matematika yang berarti "ukuran" (proportion), "relasi" (relation), dan “unsur"(element). Dalam konteks ini arti matematis ini sering dipadankan dengan arti filosofis sehingga logos dapat dimaknai sebagai hubungan rasional antara satu benda dengan benda yang lain, dan karena itu bisa dilihat sebagai "urutan" (order) dan "ukuran" (measure). (iv) Sejak parohan kedua abad kelima, logos digunakan untuk menggambarkan "rasio" (kemampuan untuk berpikir) "akal" (reason), dan "pikiran" (mind) atau "roh" (spirit), dan "gagasan" (thought) manusia. ${ }^{\mathrm{x}}$ Istilah ini pada akhirnya dipahami sebagai "kata" (Firman), "uraian”, "kisah", dan "pesan”. xi

Gagasan mengenai logos sebetulnya tidak dimunculkan oleh Yohanes, sebab istilah ini merupakan istilah yang umum pada zamannya. Ada beberapa tradisi, baik filsafat maupun keagamaan pra-Yohanes yang telah berbicara mengenai logos. Ada ahli yang menduga bahwa Yohanes mungkin meminjam istilah ini untuk berbicara mengenai Yesus. Berikut ini ialah pandangan beberapa aliran filsafat yang berbicara mengenai Logos.

1. Konsep Logos dalam Dunia Yunani ${ }^{\text {xii }}$

a. Heraclitus. Konsep logos Heraclitus menekankan pada dimensi interkonektifitas, dimana perannya ialah untuk menghubungkan manusia dengan dunia, manusia dengan Allah, dan manusia dengan manusia. Logos baginya ialah perkataan, pidato, dan isi dari pidato atau buku, tetapi sekaligus merupakan "kebenaran" (truth), sebab dari logos orang dapat mengatakan bahwa sesuatu itu sah ataukah tidak. Logos juga merupakan pengetahuan filosofis dimana di dalamnya tindakan dan perkataan manusia berasal. Logos Heraclitus dilihat sebagai perkataan yang bijaksana 
(oracular word) dan berfungsi untuk mengikat manusia dengan yang disebut the whole (keutuhan).

b. Kelompok Sophis. Golongan ini memahami logos dalam arti yang lebih politis, bahwa logos (yang memiliki sinonim dengan nous) dipahami sebagai kekuatan rasional yang ada dalam diri manusia, yakni kekuatan tindakan dan pikiran. Kekuatan ini dalam dunia politik dipergunakan untuk membangun pendekatan-pendekatan persuasif dan direktif.

c. Socrates dan Plato.Socrates dan Plato memiliki makna yang lebih luas. Keduanya melihat 'logos' sebagai fakta mendasar yang ada dalam kehidupan seluruh komunitas. Disini ia membedakan logos dalam dua jenis, yakni logos dari jiwa yang berpikir (logos of the thinking soul) dan logos dari objek atau benda (logos of the things).

d. Aristoteles. Aristoteles ialah filsuf terakhir yang menyimpulkan pandangan klasik mengenai keberadaan manusia sebagaimana dalam pernyataannya logon de monon anthropos eksei ton soon. Manusia memiliki logos (perkataan) dalam dua arti, yakni apa yang dilakukan ditentukan oleh logos (perkataan) dan logos dipandang sebagai sumber dari kebaikan manusia.

2. Konsep Logos dalam Helenisme ${ }^{\text {xiii }}$

a. Stoa. Dalam Stoa, istilah logos menunjuk pada sifat dunia dan merupakan konsep yang sejajar dengan Allah. Logos ini ialah dasar universal dari dunia dan yang menciptakan dan menguasainya (soon logikon). Dunia ini dianggap sebagai bentangan yang luas dari logos yang bekerja secara imanen di dalam segala sesuatu.Logos dipahami sebagailogos spermatikos, yakni yang menentukan keberadaan ciptaan. Logos juga merangsang pengetahuan dan tindakan moral manusia. Segala sesuatu berasal dari logos dan akan kembali kepadanya.

b. Neo-Platonisme.Logos disini dipahami sebagai kekuatan yang membentuk dan memberi hidup bagi segala sesuatu. Oleh karena itu, konsep Logos neoplatonisme berkaitan erat dengan konsepsoe (kehidupan). Logos merupakan kekuatan yang menciptakan atau membentuk segala sesuatu. 
Ketika logos bekerja semua pun diserap (lelogotai) dan dibentuk (memorphotai). Dunia secara utuh dipandang sebagai tempat logos.

c. Misteri.Dalam tradisi misteri Hellenistik, logos dipahami dalam hubungan dengan penyataan diri ilahi. Misalnya, Osiris yang dilihat merupakan wujud personifikasi logos yang diciptakan oleh Isis. Begitu juga dengan Hermes yang mengungkapkan bagaimana ia menjadi logos dan karena itu pula menjadi huios theou. Keduanya menggambarkan bahwa logos berkaitan dengan dimensi ilahi, atau musterion (misteri) dan telete (tujuan akhir hidup). Selain itu, logos juga diartikan oleh tradisi ini sebagai jalan yang menghubungkan doa-doa manusia kepada Tuhan. Apollonius dari Tyana menulis bahwa doa-doa harus dibawa melalui logos. Dengan ini, logos menunjukan kepada manusia jalan. ${ }^{\text {xiv }}$

\section{Konsep Philo dari Alexandria}

Philo dari Alexandria (20 SM - $70 \mathrm{M}$ ) jugamemiliki pandangan tersendiri mengenai logos. Dalam mengembangkan filsafatnya, ia bergantung pada pemikiran Plato, Stoa dan tradisi monoteistik Yahudi (bahkan pemikirannya merupakan sintesa dari tiga tradisi ini). ${ }^{\mathrm{xv}}$ Kleinknecht memperlihatkan hal yang sama, bahwa integrasi ini nampak dalam penggunaan istilah filsafat Helenistik dalam konsep Philo, tetapi tentunya sudah dengan nuansa mitologis yang baru dan berbeda. ${ }^{x v i}$ Konsep logos merupakan konsep penting baginya, terbukti ketika ia menggunakannya sebanyak 1400 kali dalam semua tulisannya. ${ }^{\text {vii }}$ Philo melihat bahwa logos merupakan figur perantara antara Allah dan dunia.

Konsep Plato yang mempengaruhi pikiran Philo yaitu gagasan mengenai kosmos atau dunia, bahwa dunia yang ada sekarang ini bukanlah satu-satunya dunia atau dunia yang nyata. Ada suatu realitas dunia lain yang abadi yang terpisah dari dunia yang selama ini dipahami dengan perasaan (sense) dan hanya dapat diketahui dengan akal (mind). Memang Plato tidak memberi pembedaan yang jelas di antara keduanya, namun pemilihan ini mengindikasikan adanya suatu dunia yang ideal (otherperfect world). Sementara itu, gagasan Stoa tentangdivine reason ${ }^{\text {xiii }}$ mempengaruhi pandangan Philo bahwa firman sebetulnya imanen di dalam dunia, menyerap segala sesuatu, dan hadir di dalam manusia. 
Sedangkan, pandangan tradisi monoteisme Yahudi tentang hukum-hukum Yahudi sebagai manifestasi tertinggi dari penyataan Allah dan kebenaran ilahi juga diserap dalam fisalafat Philo.

Ketiga pandangan tadi mempengaruhi pikiran Philo tentang peranan Logos sebagai perantara atau penghubung antar dua dunia (pikiran Plato). Logos ini ialah pikiran Allah yang diekspresikan di dalam pemahaman, sehingga dengannya dunia yang ideal itu dapat dipahami. Hanya melalui logos, Allah mencapai ciptaanNya, yakni dengan memasuki area yang berada dalam jangkauan persepsi manusia. ${ }^{x i x}$ Sebagai figur sentral yang memegang fungsi intermediatif, logos itu telah ada sejak awal atau bersifat pra-eksisten dan mengambil peran dalam aktifitas penciptaan. Hal ini diungkapkan secara implisit dalam tulisan-tulisannya, namun tetap menandaskan kedudukan logos sebagai "yang terutama" dari segala sesuatu yang diciptakan. Dengan menekankan peran intermediatif logos yang praeksisten ini, Philo pada saat yang bersamaan menekankan pada eksistensi logos yang dibedakan dari Allah. Kleinknecht mengatakan bahwa ketika Philo menggunakanpadanan kata logos theou atau theios logos, maka konsep Logos Philo sekaligus dibedakan dari konsep Stoa yang seolah-olah melihat logos sebagai Allah. Ia merupakan 'allah', namun dengan kedudukan kedua. ${ }^{\mathrm{x}}$

4. Tradisi Perjanjian Lama

Konsep "Firman" dalam Perjanjian Lama merupakan konsep utama yang sering muncul dan selalu dipadankan dengan Allah. Istilah Ibrani yang dipakai ialah dabhar Yahweh yang mengandung arti "Firman Allah". Dunn mengidentifikasi bahwa kemunculannya di dalam PL sebanyak 240 kali, dimana 90\% lebih penggunaannya diarahkan untuk menggambarkan aktifitas profetik nabi yang dilihat menyatakan kehendak Allah. ${ }^{x i}$ Hal yang mendasar dalam konsep Ibrani adalah keyakinan bahwa Yahweh menyatakan kehendakNya secara langsung kepada umatNya melalui inspirasi dan penglihatan kenabian. ${ }^{\text {xii }}$ Teksteks yang memperlihatkan penggunaan ini misalnya di dalam Kej.15:1; U1. 5:5; Yos.8:27; 2 Sam. 7:41; 1 Rj. 13:20, kitab Yeremia dan Yehezkiel, dll. Oleh karena itu, perkataan kenabian bukan merupakan hal yang terpisah dari Yahweh, melainkan apa yang disebut Dunn "the Word of Yahweh, the utterance of Yahweh, 
Yahweh himself speaking". Sebagai entitas ilahi yang mengungkapkan kehendak Allah melalui peran profetis, maka Firman ini dilihat seperti suatu tindakan Allah untuk berelasi dengan ciptaan, sebab Firman ini sendiri memiliki peran kreasionis (creative power), sebagaiman peran penyataan (revelation) dan penyelamatannya (salvation). Pollard telah lebih awal menekankan hal ini, bahwa konsep dabhar Yahweh PL menekankan pada Firman yang dinyatakan dan bersifat kreatif, yang dari padanya langit dan bumi diciptakan dan para nabi mendapat inspirasi. ${ }^{\text {xiii }}$

Selain tradisi PL, tradisi Hikmat juga mengenal gagasan Firman atau Logos. Firman dalam tradisi Hikmat diyakini (i) telah ada sejak awal (Ams. 8:22/LXX; Kej. 1:1), dan (ii) bersama-sama dengan Allah (Ams. 8:23-5, 30). ${ }^{\text {xiv }}$ Mungkin dalam konteks ini analisa Dodd benar, bahwa baik istilah Logos atau Firman (dan juga Roh) adalah frase-frase yang digunakan untuk menggambarkan tiga aktifitas ganda Allah sebagaimana disebutkan di atas tadi.

5. Tradisi Perjanjian Baru ${ }^{\mathrm{xxv}}$

Konsep logos juga muncul dalam kitab-kitab Perjanjian Baru. Dunn memperlihatkan bahwa dalam tulisan-tulisan Paulus, logos menunjuk pada Kristus atau apa yang disebut dengan kabar baik, sebagaimana di dalam I Tes.2:13; Rm.9:6; I Kor.14:36; II Kor.2:17; 4:2; Fil.1:14 dan Kol 1:25. Paulus menyebut kabar baik yang ia beritakan itu sebagai "firman Tuhan" (I Tes.1:8; II Tes.3:1), “firman Kristus” (Kol.3:16), “firman Salib” (I Kor.1:18), “firman yang mendamaikan" (II Kor.5:19), “firman kebenaran" (Ef.1:13; Kol.1:5), “firman kehidupan" (Fil.2:16), dan bahkan hanya sebagai "firman" (Gal.6:6; Kol.4:3; I Tes.1:6). Paulus kemudian mengidentifikasi kabar baik itu dengan Yesus(I Kor.3:16).Yesus menjadi sentra dari kabar baik, sehingga berbicara mengenai kabar baik ialah berbicara mengenai Yesus (Yesus sebagai inti kerugma).

Dalam tradisi Sinoptik Yesus mengidentifikasi proklamasi dan pengajarannya sebagai "firman" dan memberi arti yang lebih mendalam terhadapnya (Mrk.8:38; Mat.7:24). Selain itu, para penginjil juga menyebut tulisan-tulisan mengenai khotbah Yesus sebagai Injil atau bahkan firman, misalnya dalam Mrk.2:2; 4:14-20; 4:33; 8:32; 9:10. Lukas juga menyebut kerugma sebagai firman Allah (Kis.4:31; 6:2, dll), firman Tuhan $(8: 25 ; 13: 49$, dll) 
dan bahkan dengan sederhana sebagai 'firman' (4:4; 6:4; 8:4, dll), sejajar dengan 'firman keselamatan' (13:26), 'firman injil' (15:7), dan 'firman anugerah' (20:32). Selain tulisan-tulisan Paulus dan tradisi Sinoptis di atas, surat Ibrani juga berbicara mengenai firman ketika mengidentifikasi injil Kristen (Christian gospel) sebagai firman (Ibr.5:13; 6:1; 13:7, dan 4:12).

\section{LOGOS DALAM INJIL YOHANES}

Banyak ahli yang berpendapat bahwa gagasan logos yang dikembangkan oleh Yohanes turut dipengaruhi oleh tradisi-tradisi pemikiran di atas tadi. Saya sendiri sepakat dengan asumsi ini, sebab ada banyak kesamaan gagasan yang dapat ditemukan di dalam tulisan Yohanes, terutama di bagian prolog injilnya (Yoh.1:1-18). Sekalipun demikian, penggunaan tradisi lain sebagai referensi tidak lalu membuat Yohanes kehilangan keotentikan dan originalitasnya, sebab eksplorasi terhadap konsep itu membuat ia mengelaborasi pemikirannya yang khas dengan tujuan agar komunitas pembacanya dapat memahami gagasan kristologisnya. ${ }^{\text {xxi }}$ Mungkin disini John Macquarrie benar saat mengatakan bahwa penggunaan yang signifikan atas tradisi lain, tidak membuat Yohanes sama saja dengan semuanya. Sebaliknya Yohanes bergerak melampaui pandangan Yahudi maupun Yunani tentang logos. Yohanesmenggambarkan logos dalam bahasa hipostase, yakni suatu entitas yang tidak hanya 'dipersonifikasikan' tetapi juga 'dipersonakan'. xxvii Hal ini sejajar dengan apa yang ditunjukan oleh Dunn tentanggagasan "Firman menjadi daging" yang tidak memiliki pararel dalam pemikiran Yahudi Kristen. Baik pemikiran Philo, filsafat Yunani, maupun konsep Yahudi tidak bisa memahami gagasan logos menjadi daging, namun Yohanes mampu menunjukan hal ini saat memproklamirkan bahwa logos sarks egeneto (Firman menjadi daging)". xxviii Philo memang mensinyalir adanya peran intermediatif logos yang menjembatani dua realitas, namun tidak bermuara pada upaya identifikasi atas entitas logos yang personal. Ia tidak pernah melihat logos sebagai sesuatu yang bermateri atau pribadi yang nyata dengan fungsi khusus yang berbeda dengan Allah. Afirmasi ini sekaligus menekankan titik transisi dari pikiran ganda Yohanes mengenai "pra-eksistensi" ke "sejarah" ciptaan atau 
mengikuti apa yang Dunn katakan "not only the transition in the thought of the poem from preexistence to incarnation, but also in transition from imprersonal personification to actual person ${ }^{x x i x}$. . Transisi ini merupakan pikiran tematis yang paling penting bagi Yohanes, sebagai tanda bahwa inkarnasi telah dimulai dalam pentas sejarah ciptaan.

Kembali pada isu kesejajaran, Dunn memberi keterangan terperinci mengenai konstruksi prolog yang mengakomodir berbagai tradisi pemikiran yang diadopsi oleh Yohanes sebagaimana juga perbedaannya dengan mereka. Misalnya, ayat 4-5 prolog injil mengidentifikasi logos sebagai 'terang'. Gagasan ini sejajar dengan tradisi Hikmat (Hik.7:26) dan pandangan Philo. Ayat 10-12 juga mengandung pikiran tradisi Hikmat tentang hikmat yang ditolak oleh manusia, namun diungkapkan kepada Israel melalui Taurat (Sir.24: Bar.3:9-4:4; I Enokh 42). Di samping itu, ada ahli lain seperti Craig S. Keener ${ }^{\mathrm{xxx}}$, Barret $^{\mathrm{xxxi}}$, dan Kittel $^{\mathrm{xxxii}}$ yang menduga bahwa penekanan dimensi pra-eksistensi logos dalam ayat 1-3 memperlihatkan kesejajaran yang sangat erat dengan pemikiran Perjanjian Lama,terutama Kejadian 1 yang menggambarkan aktifitas penciptaan Allah. ${ }^{\text {xxiii }}$ Konstruksi kalimat prolog Yohanes dengan pernyataan pembukaan dalam narasi penciptaan nampaknya mirip. Keduanya sama-sama memulai dengan menggunakan frase "pada mulanya", namun perbedaannya terletak pada subjek dalam pernyataan itu, dimana narasi Kejadian menggunakan nama "Allah" dan prolog Yohanes menggunakan "Logos". Perbedaan inilah yang membuat logos Yohanes bersifat pra-eksisten.

Sampai di sini saya melihat adanya skema linear dari pikiran Yohanes mengenai logos, bahwa logos yang pra-eksisten itu akan menjadi eksisten dalam pentas ciptaan. Disinilah tema "pra-eksistensi ke inkarnasi" menjadi alur pemikiran Yohanes. Mungkin dalam kerangka ini, dapat dilihat peran mediatif ganda dari logos, yakni sebagai agent of creation, revelation, and salvation.

Sebelum masuk pada pembahasan mengenai tiga peran logos ini, perlu juga untuk melihat konteks yang terjadi pada saat Yohanes tampil dengan gagasan logosnya ini. Beberapa ahli mengemukakan konteks dominan dari Yohanes ialah (i) munculnya filsafat Helenisme, terutama aliran Gnostik, (ii) pemilahan gereja 
dengan sinagoge, (iii) munculnya kelompok pengikut Yohanes Pembaptis atau Baptist Group, serta (iv) menguatnya Imperial Cult Ideology, suatu ideologi yang mempromosikan kaisar Agustinus sebagai tuhan.Mungkin dalam rangka menanggapi konteks-konteks ini Yohanes sangat menekankan pada isu kristologis, terutama kristologi logos dengan tujuan untuk menegaskan posisi Yesus yang melampaui semua filsafat atau ideologi dan gerakan bidat yang berkembang saat itu. Disinilah ia secara sengaja menampilkan tiga peran agensi Yesus tadi.

Pertama, sebagai entitas yang pra-eksisten logos memiliki peran sebagai mediator dalam aktifitas penciptaan (disini nampak ada kesejajaran dengan gagasan Stoa). Yohanes memberi aksentuasi yang tajam atas gagasan ini melalui pernyataan panta di autou egeneto (terj. Ay.3. 'segala sesuatu dijadikan oleh Dia'). Panta meliputi human dan non-human sebab istilah ini tidak semata berdimensi antropos, melainkan kosmologis. Ide yang paling penting disini ialah baik'antropos' maupun 'kosmos' merupakan produk kreasionis Allah dan logos. Dengan begitu, logos menjadi figur sentral dalam tindakan penciptaan Allah. Dengan menekankan aspek praeksistensi yang kreatif inilah, Yohanes sekaligus melampaui pikiran tradisi lain yang melihat logos sebagai yang diciptakan atau bahkan yang sulung dalam penciptaan, sebagaimana gagasan Paulus dalam Kol.1:15-17 yang menyebut Yesus sebagai "yang sulung, lebih utama dari yang diciptakan". Sekalipun demikian, logos dalam persepsi Yohanes tidak sama dengan Allah. Logos bukan Allah, tetapi memiliki sifat keilahian yang tidak dapat dipisahkan dari Allah. ${ }^{\text {xxiv }}$ Konstruksi gramatikal yang dipergunakan oleh Yohanes menunjukan hal ini. Yohanes tidak menggunakan kataeks (dari) untuk menunjukan aktifitas penciptaan,tetapidi (melalui), sehingga kedudukan logos ialah kedudukan sekunder setelah Allah. Preposisi di ini sekaligus menekankan peran mediatifnya, sebab di mengandung makna "intermediasi" yang dibedakan dari eks yang menunjuk pada "sumber". Pembedaan antara Allah dengan logos juga muncul ketika di bagian awal prolog Yohanes mengafirmasi bahwa Theos en ho logos (ay.1c). Pernyataan ini sering disalahartikan sehingga terjemahannya seolah-olah "Allah ialah Firman" atau sebaliknya "Firman ialah Allah". 
Konstruksi gramatikal ini sebetulnya mesti dipahami sebagai usaha untuk menyifati Logos (logos memiliki sifat keilahian). Selain itu, analisa linguistik pun telah membuktikan bahwa dalam bahasa Yunani untuk menyebut Allah, maka kata "Theos" harus disertai dengan kata sandang 'ho' (kata benda selalu didahului dengan kata sandang). Sebaliknya, ketiadaan kata sandang mengharuskan suatu kalimat dipahami dalam nuansa pensifatan (kata sifat). Dengan demikian, maka logos dalam wacana penciptaan dilihat sebagai entitas yang dibedakan dari Allah, namun mengandung kualitas keallahan!

Kedua, logos Yohanes juga merupakan mediator bagi penyataan diri Allah (God's agent of revelation). Hal ini diungkapkan secara eksplisit dalam1:17-18 dan juga di luar prolog seperti 8:19, 38; 14:7, 9; dan 17:25. ${ }^{\text {xxx }}$ Gagasan ini diadopsi oleh Yohanes dari tradisi Perjanjian Baru, terutama Ibrani 1 dan ucapanucapan sumber Q seperti, “tidak ada seorangpun yang mengenal Bapa kecuali Anak dan orang yang kepadanya Anak itu berkenaan menyatakannya" (Mat.11:27; Luk.10:22). Lebih dari itu, Dunn menduga bahwa pernyataan ini dipengaruhi oleh pemikiran Yahudi (bd. Kel.33:20; U14:12). ${ }^{\text {xxvi }}$ Pollard menunjukan bahwa idea mengenai Yesus sebagai manifestasi penyataan diri Bapa, atau setidaknya sebagai seseorang yang melaluinya Allah menyatakan diri, terungkap dalam seluruh Injil Yohanes. Kemuliaan Bapa dapat dilihat di dalam semua tindakan dan perkataan Anak. ${ }^{\text {xxvii }}$ Satu hal menarik dari penyataan diri Allah sebagaimana dalam ayat 18-19 ialah bahwa Yohanes tidak lagi menggunakan istilah logos untuk merujuk pada subjek yang dimaksudkan olehnya, melainkan menggunakan istilah "Anak tunggal Allah". Dunn memperlihatkan perubahan gelar kristologis ini dengan mengatakan bahwa Yohanes memang sengaja memakai istilah "anak tunggal Allah" untuk menunjuk pada logos, sehingga pembaca menangkap pesan bahwa Yesus ialah logos dan sekaligus Anak Tunggal Allah.

Agak berbeda dengan Pollard, saya melihat bahwa konsep penyataan sebetulnya tidak dimulai dalam ayat 17-18 tetapi telah muncul dalam ayat-ayat sebelumnya, secara khusus ayat 14. Frank J. Matera pun menegaskan bahwa gagasan penyataan sudah muncul dalam klausa logos sarks egenetoyang 
mempersiapkan komunitas pembaca untuk memahami teks-teks prospektif yang

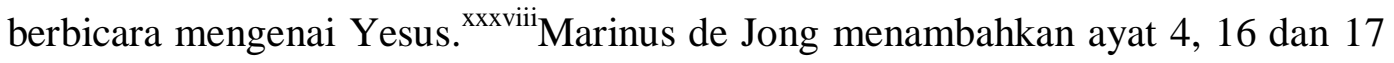
selain ayat $14 .^{\text {xxxix }}$

Pertanyaan penting disini ialah apa makna logos sebagaiGod's agent of revelation? Disini analisa Pollard penting untuk diperhatikan. Pollard mengatakan bahwa peran revelatif logos ialah untuk menunjukan bagaimana Allah dan apa kehendakNya. Oleh karena itu, logos di dalam perkataan dan tindakanNya menampilkan Allah yang sebenarnya. Mungkin untuk hal inilah, Yohanes mengatakan bahwa komunitas telah melihat "kemuliaanNya" (ay.14b). Konsep "kemuliaan" Yohanes penting untuk diperhatikan.

Yohanes secara dominan menggunakan istilah kemuliaan dalam hubungan dengan mujizat (tanda) yang dilakukan oleh Yesus $(2: 11 ; 11: 14,40)$. Tanda-tanda seperti: air berubah menjadi anggur di Kana, penyembuhan seorang anak perwira, penyembuhan orang lumpuh di kolam Bethesda, pemberian makan lima ribu orang, penyembuhan orang buta, dan bahkan kebangkitan Lazarus merupakan cara untuk memperlihatkan kemuliaan Allah. Pernyataan yang sangat eksplisit dari hal ini, menurut Andreas J. Kostenberger nampak dalam peristiwa di Kana. ${ }^{\mathrm{xl}}$ Karena itu, kesaksian bahwa "kami telah melihat kemuliaanNya" dalam ay.14c merupakan suatu kesaksian apostolis mengenai seluruh karya Yesus. Hal yang tidak kalah penting untuk ditekankan disini ialah kenyataan bahwatanda-tanda mujizat yang menampilkan Allah tidak hanya dilakukan hanya untuk pengikut Yesus saat itu, melainkan juga kepada dunia luar yang tidak percaya kepadaNya. Banyak orang dalam komunitas yang hadir pada pesta di Kana, kelompok orang banyak yang mengikutiNya dan orang-orang yang disembuhkanmerupakan kelompok orang-orang di luar komunitasNya. ${ }^{\text {xli }}$

Akhirnya peran logos yang lain ialah peran penyelamatan (agent of salvation). Fungsi mediatif ini muncul dalam 1:12 dan sejajar dengan ungkapanungkapan salvivic lainnya seperti 1:29 (Yesus ialah anak domba Allah yang menghapus dosa dunia); 4:47 (penyelamat dunia); 3:16 (anak tunggal yang diutus Bapa sehingga yang percaya kepadanya akan memperoleh hidup yang kekal); 3:17 (dunia diselamatkan melalui dia); 6:40; 10:10, 28; 18:3; 20:31 (sumber hidup 
yang kekal); dan 8:35; 8:38 (keselamatan datang melalui iman kepadanya). Surat Yohanes juga mengeksplisitkan hal ini, misalnya dalam 1 Yoh 1:7; 2:1-2; dan 4:9$10 .^{\text {xlii }}$

Berdasarkan prolognya, dapat dilihat bahwa Yohanes mengaitkan keselamatan dengan status sebagai "anak-anak Allah" (tekna Theou). Istilah Yunanitekna sering digunakan untuk menjelaskan hubungan manusia dengan Allah dan dibedakan dari huios yang menjelaskan hubungan Yesus dengan Bapa. Semua orang dapat disebut dengan tekna dan ini sekaligus mengungkapkan dimensi universalitas Allah yang melampaui identitas-identitas sosial, sebab tidak hanya golongan manusia tertentu yang berhak memperoleh status ini, tetapi 'semua' (panta). Yohanes tidak hanya mengkhususkan istilah ini bagi komunitas pengikut Yesus saat itu saja (apalagi mengidentifikasikannya dengan istilah kekristenan), tetapi kepada kosmos dimana keseluruhan anthropos berada. Bahkan, sebelum pernyataanini muncul, Yohanestelah melontarkan kritik yang tajam terhadap sikap orang-orang yang disebut sebagai "kepunyaanNya" yang justru menolakNya. Ia kemudian menunjukan bagaimana orang disebut sebagai tekna ketika ia menempatkan "percaya" (pisteusosin) sebagai syarat. Menurut saya, kriteria ini tidak dapat diartikan dengan "konfesi" apalagi "status" sebagai orang Kristen, sebab maknanya melampaui aspek verbalitas, namun mengakar pada dimensi praksis. Pemaknaan akan istilah ini harus diselaraskan dengan konteks penggunaannya dalam 14:12 (barangsiapa percaya kepadaKu, ia akan juga melakukan pekerjaan-pekerjaan yang Aku lakukan, bahkan pekerjaanperkerjaan yang lebih besar dari pada itu). Pemaknaan seperti ini merujuk pada criteria'praksis'. Dengan begitu, piesteusosin dalam injil Yohanes sangat menitikberatkan pada dimensi praksis.

Sampai di sini dapat disimpulkan bahwa fungsi penyataan yang dimainkan oleh Yesus yakni untuk memanifestasikan Allah atau menyatakan 'kemuliaan' (dalam terang makna tadi) serta memperjuangkan kemanusiaan melalui berbagai tindakan liberatif atau pembebasan yang dilakukannya melalui 'tanda' atau 'mujizat'. 


\section{Interpretasi Kristologi Logos dalam Konteks Pluralisme Agama di Indonesia}

Sebagaimana telah disinggung pada bagian awal artikel ini, bahwa para teolog pluralisme, seperti halnya John Hick yang menentang kristologi inkarnasi sebuah kristologi yang berdasar pada gagasan logos sarks egeneto. Usungan terhadap dimensi universalisme dalam teologi agama-agama telah membuat Hick mengabaikan dimensi partikularisme yang dilihatnya sebagai dasar eksklusifisme Kekristenan. Padahal, teologi maupun dialog yang dibangun bisa berakar pada dimensi partikularisme tadi dan tidak mesti dianggap sebagai ancaman semata. Hal ini karena dimensi partikularisme dalam suatu tradisi sebetulnya bisa memberi kontribusi dalam pengembangan teologi yang menopang hubungan dan dialog antaragama.

Partikularisme di sini tidak serta merta diartikan sebagai eksklusifime, tetapi dilihat sebagai suatu keunikan (uniqeness). Pengabaian terhadap keunikan masing-masing tradisi akan membuat agama-agama terjebak dalam relativisme, yakni pandangan yang menganggap seolah-olah semua agama sama.Pluralisme agama sendiri tidak berarti bahwa semua agama-agama harus disatukan sebagaimana gagasan uniformisme, tetapi perbedaan dan keragaman diapresiasi sedemikian rupa dalam semangat keterbukaan (openess) dan tetap mengutamakan prinsip konsistensi terhadap tradisi iman seseorang (commitment). Dua kriteria ini menjadi penting dalam pluralisme agama.

Dalam konteks ini, saya melihat bahwa kristologi logos sebagai dasar bagi konstruksi pemahaman inkarnasi, dalam level yang sangat praktis, dapat juga memberi kontribusibagi pengembangan teologi pluralisme yang apresiatif terhadap perbedaan, bahkan dapat mendorong dialog praksis (living dialogue) antar agama. Memang disadari bahwa pemaknaan literal terhadap gagasan inkarnasi dapat menjebak seseorang dalam pemahaman eksklusifisme yang sempit. Tetapi interpretasi terhadap kualitas logos, sebagai 'core' dalam gagasan inkarnasi Kristen telah menunjukkan bahwa kristologi ini memiliki sisi lain yang bisa disumbangkan untuk membangun suatu teologi agama-agama yang liberatif. Dimensi liberatif dari 'logos' atau inkarnasi merupakan dasar bagi teologi Kristen 
yang mempromosikan keadilan, perdamaian, dan pembebasan di tengah masyarakat majemuk.

Berdasarkan penelusuran terhadap konsep biblis mengenai Logos, terutama dalam injil Yohanes, maka ada dua pokok pikiran kontributif dari kristologi logos Yohanes yang bisa dipertimbangkan dalam konteks wacana teologi agama-agama.

\section{a. Universalisme Logos sebagai Gagasan Kristologi Penciptaan}

Jika membaca narasi logos Yohanes dengan teliti, maka dapat ditemukan bahwa gagasan pluralisme sebetulnya muncul secara eksplisit. Yohanes mengawali Injilnya dengan menggambarkan bahwa penciptaan "semua" (panta) sangat berkaitan erat dengan peranan logos. Sebagaimana telah disinggung di atas, panta disini tidak bernada antropos apalagi antropos yang pragmatis, yakni yang dibedakan dalam identitas sosial tertentu seperti agama, suku, dll. Sebaliknyapanta lebih bersifat kosmik dan karena itu kedudukannya universal. Yang paling menarik dari penciptaan atas panta ini ialah adanya intervensi logos. Berbeda dengan tradisi PL, Yohanes mengambil langkah lanjut untuk mengidentifikasi logos sebagai yang turut memiliki andil dalam tindakan kreasionis. Dalam kerangka inilah, konsep "kristologi penciptaan" dapat dipertimbangkan sebagai dasar perjumpaan agama-agama.

Dalam mengembangkan teologi agama-agama, para ahli kemudian berupaya untuk mencari dasar universal yang dapat menjembatani hubungan antar agama. Untuk maksud inilah, maka banyak yang merujuk pada gagasan teologi penciptaan. Teresa Okure, misalnya, dalam menjawab pertanyaan mengenai kemungkinan munculnya suatu interfaith theology (teologi lintas iman) yang universal mengatakan bahwa konsep "One God, Creator of all" harus diutamakan. Idea ini sekaligus menegaskan bahwa semua manusia merupakan spesies yang sama yang berasal dari satu sumber yaitu Allah yang merupakan pencipta dan karena itu semua manusia berada dalam suatu interconnectedness sebagai the human family. xliii Saya tidak sepenuhnya setuju dengan gagasan ini, sebab jika Okure hendak menekankan dimensi "all" maka penekanannya harus melampaui aspek antropos, tetapi kosmis, sehinggathe human family menjadithe 
creation family (mencakup human dan non-human). Emanuel Gerrit Singgih juga pernah menawarkan idea ini. Menurutnya, kitab Kejadian 1-11 dan bagian-bagian Alkitab lain yang mengakui universalitas Allah sebagai pencipta dan alam semesta (termasuk manusia) sebagai ciptaan harus menjadi dasar teologis bagi kehidupan kristiani dalam masyarakat keagamaan yang bersifat majemuk. ${ }^{\text {xliv }}$

Benar bahwa teologi penciptaan yang sangat kental dengan dimensi teosentris (dalam arti tertentu bisa disebut universalis) bisa dijagokan sebagai dasar perjumpaan agama-agama. Kendatipun begitu, kristologi penciptaan sebetulnya bisa dipertimbangkan sebagai tawaran lain. Kristologi ini tidak dalam rangka memaksakan semua agama untuk mengakui kedudukan dan peran logos (baca: Yesus), melainkan lebih bersifat internal dalam mendorong penghayatan kekristenan untuk berjumpa dengan agama-agama lain dan memandang mereka sebagai bagian dari the creation family. Jika Yohanes melihat logos sebagai cocreatorAllah, maka kekristenan harus mengambil langkah praksis untuk membangun harmoni dengan agama lain sebagai bentuk aktualisasi konfesional atas peran logos yang meliputi semua. Hal ini berarti bahwa bentuk pengakuan akankedudukan logos sebagai co-creatoryang menciptakan 'semua' ialah dalam cara pandang dan tindakan relasional kekristenan dengan agama-agama lain yang bersifat inklusif dan apresiatif.

\section{b. Kristologi Logos: "Kristologi Pembebasan Agama-agama"}

Satu hal penting dari logos sebagaimana dibahas di atas ialah peranannya untuk menyatakan kemuliaan Allah. Ini merupakan aktifitas dominan logos, yakniuntuk memanifestasikan Allah melalui "tanda-tanda" (semeia) yang dilakukanNya. Injil Yohanes mencatat bahwa semua tanda-tanda itu terwujud dalam tindakan-tindakan penyembuhan orang buta, memberi makan lima ribu orang, penyembuhan orang sakit, dll. Tindakan-tindakan ini merupakan praksis pembebasan yang dikerjakan oleh "Logos yang menjadi manusia" (logos sarks egeneto). Praksis pembebasan ini melepaskan orang-orang dari penderitaan serta pada saat yang bersamaan meningkatkan kualitas hidup. Di sinilah pembebasan menjadi isu utama dalam inkarnasi logos. Mungkin untuk hal ini Aloysius Pieris 
benar dalam menawarkan idenya mengenai liberation christology of religion $^{x l v}$ yang dibedakan dari gagasan Knitter, liberation theology of religions. ${ }^{x l v i}$ Pieris mengatakan bahwa Yesus menjadi fakta dan perjanjian Allah dengan kaum miskin dan perjanjian itu diwujudkan dalam keberpihakanNya terhadap mereka dan mengkritisi kekuatan-kekuatan mamonis yang melahirkan ketidakadilan dan penderitaan. Peran Yesus ini ialah unik dan gagasan inipun ialah gagasan unik yang tidak dapat ditemukan dalam tradisi lain. ${ }^{\text {xlvii }}$

Jika peran revelatif logos ialah peran ganda, yaitu untuk memanifestasikan Allah dan untuk membebaskan manusia dari penderitaan, maka kekristenan juga dalam konfesi terhadap logos harus berorientasi pada dua hal ini. Pemuliaan terhadap Allah tidak dapat dilepaskan dari praksis yang membebaskan manusia dari penderitaan, karena kedua hal ini saling menemukan maknanya ketika dilakukan secara seimbang. Yang mau dikatakan disini ialah bahwa konfesi kekristenan tidak harus membuat kekristenan lupa bahwa ada "realitas pincang" dalam masyarakat majemuk yang disebut dengan kemiskinan, penderitaan, diskriminasi sosial, krisis ekologi dan berbagai realitas lain yang problematik. Realitas-realitas ini merupakan masalah global bagi semua agama sehingga kekristenan harus bergerak bersama dengan agama-agama lain. Disinilah realitas ini menjadi dasar bagi perjumpaan agama-agama, bagi dialog yang sejati. Harvey Cox dengan "pengutamaan kaum miskin". xlviii

\section{Endnote :}

\footnotetext{
iMaurice Wiles, "Christianity Without Incarnation" dalam The Myth of God Incarnate, Ed. John Hick (London: SCM Press, 1977), hlm1.

iijames Dunn, Christology in the Making. (Grand Rapids: William B. Eerdmans Publishing Company, 1980), hlm.1.3.

iii Magapul Sagala, Firman Menjadi Daging. (Jakarta: Perkantas, 2009), hlm. 65.

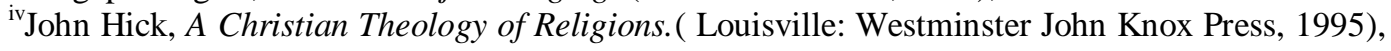
hlm. 87.

"Hick, A Christian Theology of Religions, hlm. 95.

"Li Leslie Houlden, "The Creed Experience" dalam The Myth of God Incarnate, Ed. John Hick (London: SCM Press, 1977), hlm. 125-132.

${ }^{v i i}$ Sagala, Firman Menjadi Daging, hlm.65.

viiiT. E. Pollard, Johanine Christology and the Early Churc, (Cambridge: Cambridge University Press, 1970), hlm.5.
} 
${ }^{\mathrm{ix}} \mathrm{C}$. K. Barrett, The Gospel Accroding to Saint John, (London: Presbyterian Publishing Corporation, 1958).

"Kleinknecht. "The Logos in the Greek and Hellenistic World, "Theological Dictionary of the New Testament. Eds. Gerhard Kittel (Grand Rapids: William B. Eerdmans Publishing Company, 1967), hlm.77-78.

${ }^{x i}$ Sagala, Firman Menjadi Daging, hlm.41

xii Kleinknecht, "The Logos in the Greek and Hellenistic World", hlm.80-84

xiii Kleinknecht, "The Logos in the Greek and Hellenistic World", hlm.84-88.

${ }^{x i v}$ Selain tiga tradisi Helenistik ini, ada juga pemikiran teologi Hermetis (Hermetism) yang menggambarkan logos dalam hubungan antara bapa dan anak, bahwa logos memiliki hubungan erat dengan Hermes.

${ }^{\mathrm{xv}}$ Dunn, Christology in the Making,hlm.221.

${ }^{\mathrm{xvi} K l e i n k n e c h t . ~ " T h e ~ L o g o s ~ i n ~ t h e ~ G r e e k ~ a n d ~ H e l l e n i s t i c ~ W o r l d ", ~ h l m .89 . ~}$

${ }^{x v i i}$ Dunn, Christology in the Making,hlm.221.

xviii'Dunn mengartikan istilah Logos Philo dengan 'reason' atau akal, pikiran, dan perkataan.

${ }^{x i x}$ Sagala, Firman Menjadi Daging, hlm.44.

${ }^{\mathrm{xx}}$ Kleinknecht. "The Logos in the Greek and Hellenistic World," hlm.89.

${ }^{\mathrm{xxi}}$ Dunn, Christology in the Making,hlm.217.

${ }^{x x i i}$ Sagala, Firman Menjadi Daging, hlm. 47.

xxiii Pollard, Johannine Christology and the Early Church, hlm.7.

${ }^{x x i v}$ Pollard, Johannine Christology and the Early Church, hlm.9.

${ }^{x x v}$ Dunn, Christology in the Making, hlm.230-232.

${ }^{x x v i}$ Pollard, Johannine Christology and the Early Church, hlm.8.

xxvii John Macquarrie, Jesus Christ in Modern Thought, (Philadelphia: SCM Press, 1990), hlm.43.

xxviii Dunn, Christology in the Making,hlm.242-243.

${ }^{x x i x}$ Dunn, Christology in the Making,hlm.243.

${ }^{\mathrm{xx}}$ Craig S. Keener, The IVP Bible Commentary: New Testament, (Illonis; Inter Varsity Press, 1993).

${ }^{x x x i}$ Lih. Barret, The Gospel According to Saint John.

${ }^{x x x i i}$ Gerhard Kittel, Theological Dictionary of the New Testament, (Michigan: 1967), hlm.131-132.

xxxiii Sagala, Firman Menjadi Daging, hlm.59. bd. Juga Barret, The Gospel According to St. John; an Introduction with Commentary and Notes on the Greek Text.

${ }^{\mathrm{xxxi}}$ Macquairre, Jesus Christ in Modern Thought,hlm.44.

${ }^{x x x}$ Lih. Pollard, Johannine Christology and the Early Church,hlm.21.

${ }^{x x x v i}$ Dunn, Christology in the Making,hlm.244.

xxxvii Pollard, Johannine Christology and the Early Church, hlm.21.

xxxviii Frank J. Matera, New Testament Christology, (Louisville: Westminster John Knox, 1999), hlm.218.

${ }^{x x x i x}$ Marinus de Jong, Christology in Context, (Philadelphia: Westminster John Knox Press, 1988), hlm.147.

${ }^{\mathrm{xl}}$ Andreas J. Kostenberger, The Mission of Jesus and the Disciples According to the Fourth Gospel, (Grand Rapids: William B. Eerdmans Publishing Company, 1998), hlm.61.

${ }^{x l i}$ Kostenberger, The Mission of Jesus and the Disciples According to the Fourth Gospel, hlm.61.

xliii Pollard, Johannine Christology and the Early Church, hlm.21-22

xliii Teresa Okure, "Is Interfaith Theology Possible? If Not, Why Not? Contribution from a Biblical Perspective" dalam Toward a Planetary Theology, ed. Jose Maria Vigil, (Montreal: Dunamis Publisher, 2010), hlm. 99.

${ }^{x l i v}$ Emanuel Gerrit Singgih, Berteologi Dalam Konteks, (Yogyakarta: Penerbit Kanisius, 2007), hlm. 238-240.

${ }^{x l v}$ Aloysius Pieris, "Toward a Theology of Religious Pluralism? Fidelity and Fairness in Interfaith Fellowship" dalam Toward a Planetary Theology, ed. Jose Maria Vigil, (Montreal: Dunamis Publishers, 2010), hlm. 127-130. 


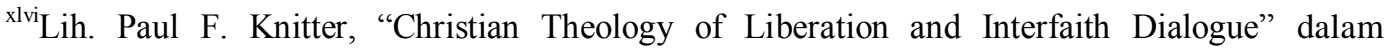
Christianity and Other Religions, eds. John Hick and Brian Hebblethwaite, (Oxford: Oneworld Publications, 2011), hlm.146-155.

xlvii Aloysius Pieris, "Toward a Theology of Religious Pluralism? Fidelity and Fairness in Interfaith Fellowship”, hlm. 127-130.

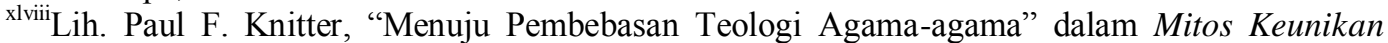
Agama Kristen, ed. John Hick dan Paul F. Knitter, (Jakarta: BPK Gunung Mulia, 2001), hlm. 288.

\section{DAFTAR PUSTAKA}

Barret, C. K. 1958. The Gospel According to St. John. London: Presbyterian Publishing Corporation..

de Jong, Marinus. 1988. Christology in Context. Philadelphia: Westminster John Knox Press.

Dunn, James. 1980.Christology in the Making.Grand Rapids: William B. Eerdmans Publishing Company..

Dunn,James. 1980. Christology in the Making. Grand Rapids: William B. Eerdmans Publishing Company.

Hick, John. 1995. A Christian Theology of Religions. Louisville: Westminster John Knox Press.

Houlden, Leslie. 1977. "The Creed of Experience”.The Myth of God Incarnate. Eds. John Hick. London: SCM Press.

Keener, Craig S. 1993. The IVP Bible Commentary; New Testament. Illinois; Inter Varsity Press.

Kleinknecht. 1967. "The Logos in the Greek and Hellenistic World".Theological Dictionary of the New Testament, Eds. Gerhard Kittel. Grand Rapids: William B. Eerdmans Publishing Company.

Knitter, Paul F.,2001. "Christian Theology of Liberation and Interfaith Dialogue", dalam Christianity and Other Religions, Ed. By John Hick dan Brian Hebblethwaite, Oxford: Oneworld Publications.

Knitter, Paul F.,2001. "Menuju Teologi Pembebasan Agama-agama", dalam Mitos Keunikan Agama Kristen, Ed. By John Hick dan Paul F. Knitter, Jakarta: BPK Gunung Mulia.

Kostenberger, 1998. Andreas J.,The Mission of Jesus and the Disciples According to the Fourth Gospel, Grand Rapids: William B. Eerdmans Publishing Company. 
Macquarrie, John. 1990. Jesus Christ in Modern Thought. Philadelphia: SCM Press.

Matera, Frank J. 1999. New Testament Christology. Louisville: Westminster John Knox.

Okure,Teresa,2010. “Is Interfaith Theology Possible? If Not, Why Not?”, dalam Toward a Planetary Theology, Ed. By. Jose Maria Vigil, Montreal: Dunamis Publisher.

Pieris, Aloysius,2010. "Toward a Theology of Religious Pluralism", dalam Toward a Planetary Theology, Ed. By Jose Maria Vigil. Montreal: Dunamis Publishers.

Pollard, T. E., 1970. Johannine Christology and the Early Church,Cambridge: Cambridge University Press.

Sagala, Mangapul. 2009. Firman Menjadi Daging. Jakarta: Perkantas..

Singgih, Emanuel Gerrit. 2007. Berteologi Dalam Konteks. Yogyakarta: Penerbit Kanisius,.

Wiles, Maurice. 1977. "Christianity without Incarnation," The Myth of God Incarnate. Ed. John Hick. London: SCM Press. 